\title{
Impact of Entrepreneurial Mindset Integration in a First- Semester Engineering Course
}

\author{
Benjamin S. Kelley \\ Baylor University School of Engineering and Computer Science
}

\begin{abstract}
During the fall semester offering of EGR 1301: Introduction to Engineering, Entrepreneurial Mindset (EM) topics were introduced as class topics on three separate occasions in two different course sections. To measure if exposure to and practice of the specific EM topic of Create Value impacted student EM awareness two different self-assessment instruments were administered to these and several other EGR 1301 sections. The first was Fulcher's Curiosity Index selfassessment survey and was administered near the beginning of the semester. The second was Carpenter's Entrepreneurial Mindset self-assessment and was administered near the end of the course. Student responses from EGR 1301 sections containing specific EM experiences were compared to responses from students in sections without specific EM exposure. Results did not indicate that students were impacted by this limited exposure to EM topics. Results indicated that a more extensive level of EM exposure would be necessary to quantitatively affect student EM awareness.
\end{abstract}

\section{Keywords}

entrepreneurial mindset, freshman, engineering education, create value

\section{Introduction}

Baylor University's School of Engineering and Computer Science has been an active participate in "a national partnership of universities with the shared mission to graduate engineers with an entrepreneurial mindset..." These efforts are coordinated by the Kern Engineering Entrepreneurial Network (KEEN) under the mantra that "it is critical for engineering schools to teach a technical skillset and an entrepreneurial mindset-fostering curiosity, connections and the creation of value" ..."so that students can create personal, economic, and societal value through a lifetime of meaningful work."

One approach used to implement KEEN EM ideals at Baylor was to commission KEEN Innovators to explore opportunities to expose students to EM topics and experiences within a classroom setting. ${ }^{1-3}$ This is more often attempted in upper-level engineering classes associated with a design project or other commercialization activity. An often cited impediment to inserting EM into the course content of lower level classes are that essential course content must be supplanted and that students are not yet at the knowledge level to have the technical maturity to be meaningfully involved in value creation projects. Others have pointed to the contrasting view that although with less depth, exposure to innovation and creativity processes allows beginning engineering students to more easily implement them in upper-level projects and classes. ${ }^{4}$

\section{Proceedings of the 2017 ASEE Gulf-Southwest Section Annual Conference Organized by The University of Texas at Dallas Copyright @ 2017, American Society for Engineering Education}


The KEEN Innovator project described here introduced EM topics within the environment of two different sections of the first-semester EGR 1301 freshman engineering course. There was not the intent to overhaul these sections as EGR 1301 is taught by several different faculty members, most using a similar calendar and learning objectives. Further, topic-specific content in EGR 1301 is intended to serve as a success platform for required follow-on courses. Rather, the intent of this effort was to broach EM topics at a low to moderate intensity and associated with easily-connected topics. To assess whether this exposure to the EM topic of value creation affected student propensity toward entrepreneurial mindedness, the results from an early-course Curiosity self assessment and a late course Entrepreneurial Mindset self assessment among students in the experimental EGR 1301sections, and EGR 1301sections offered by other faculty, were compared.

\section{Background}

The EGR 1301 course meets three times each week in a 50-minute classroom setting of around 30 students. Each section is coupled with an engineering-specific academic-success and accountability freshman seminar course that meets separately once per week in a 75-minute session in the same classroom. Except for the two EGR 1301 sessions offered by the author, the EGR 1301 and paired freshman seminar courses were taught by different individuals. There were no attempts to match or measure other differences between EGR 1301 sections such as student academic preparedness, time-of-day offering, gender, or ethnicity.

The EGR 1301 course sections participating in this study met on MWF during the time periods shown in Table I.

The engineering majors offered at Baylor are Electrical and Computer Engineering (BSECE), Mechanical Engineering (BSME), and General Engineering (BSE), with concentrations available such as Biomedical and Humanitarian Engineering. Infrequently nonengineering students enroll in the EGR 1301 class.

All of the EGR 1301 sections involved in this study included similar though not identical course outlines and topics. Major course topics included:

- Engineering profession and ethics

- Engineering problem solving process

- Engineering economics

- Engineering calculations and unit conversions with Excel ${ }^{\circledR}$ and graphing

- Statics including the analysis, design, building, and testing a model truss bridge
- Fluid mechanics

- Energy forms and conservation laws

- Electrical charge, voltage, current and circuits

- Digital logic and circuits

- Energy generation including student team presentations

The attitude of the EGR 1301 course, especially when coupled with the freshman seminar component, is one aimed at academic success, accountability, and reinforcing effective habits. To meet the eligibility

\section{Proceedings of the 2017 ASEE Gulf-Southwest Section Annual Conference Organized by The University of Texas at Dallas \\ Copyright $(\mathbb{2}$ 2017, American Society for Engineering Education}


requirements for the next engineering course requires that students earn a B or better grade in EGR 1301. The topics covered are intended to be those fundamental to engineering as well that challenge students both intellectually and time-management wise. Further, many of the course topics have direct counterparts in specific follow-on courses. But in some cases, for example ECE students relating to statics and ME students relating to digital logic, the EGR 1301 content will be their only formal engineering exposure to these topics.

\section{Approach}

Within the two sections of EGR 1301 taught by the author, EM content was intentionally inserted into the course content on three occasions relating to:

1. Engineering economics

2. Model truss bridge design, building and testing

3. Energy generation student team presentation

One reason these three approaches were chosen because their inclusion would not greatly alter the structure of the course. Another reason was because cause of their diversity of incorporation approach to include classroom lecture, a hands-on project, and student/team inquiry.

Engineering economics was chosen as an EM-associated topic because it involves monetary and project values that seemingly have a direct relationship to creating value. During this portion of the course students learn how to move money across time and how to use this approach to compare and recommend project alternatives from an economic decision-making process. The EM content used during this portion of the course was the introduction to the KEEN three C's; Curiosity, Connections, and Creating Value. This was done through direct course content informed with KEEN derived content and included the EM video depicting two recent engineering graduates considering value creation relating to a battery project rather than a more traditional engineering approach.

Within the model bridge project, the students were first introduced to the theory and concept of statics, including reaction forces and the analysis of forces in truss members using the method of joints. They also experimented with the modeling software ModelSmart ${ }^{\mathbb{B}}$ to explore the efficiency of truss members based on load capacity. From there, teams were issued a specific quantity and size of basswood and the specifications for a model bridge that would span a $25-\mathrm{cm}$ gap. In addition to these standard wood components, the teams from the two experimental EGR 1301 sections were also issued an additional $1 \mathrm{~m}$ of hobby-wire steel cabling. The teams were encouraged to use this cabling to add value to their bridge. The objective of the bridge design was to model and build a bridge with the highest ultimate load-to-weight ratio. Further, regardless of the model's weight, there was a prestige factor associated with the bridge that withstood a large ultimate load. Teams were further extorted to compete with each other, and teams from other EGR 1301 sections, to build the stoutest/strongest bridge.

The third exposure to EM was associated with the semester ending team energy presentation. Teams selected energy-production methods to research, with the end assignment being a presentation to the other members of the class. While the restrictions on the energy-production topic explored were not overly restrictive, one requirement was that the method, or

\section{Proceedings of the 2017 ASEE Gulf-Southwest Section Annual Conference Organized by The University of Texas at Dallas Copyright (C) 2017, American Society for Engineering Education}


subcomponent, had to possess novel and value-creating attributes, and these characteristics were to be showcased in the team presentation.

\section{Surveys}

The Curiosity Index self-assessment survey developed by Fulcher ${ }^{5}$ was administered during the early days of the EGR 1301 courses. This survey assesses an individual student's curiosity and yields three scores:

1. Depth: exploring/understanding new objects, events, and ideas.

2. Breadth: Seeking varied and changing experiences.

3. Total curiosity.

The survey was administered through the assistance of Julia Williams and Timothy Chow of Rose Hulman Institute of Technology, ${ }^{6}$ who have developed an online survey instrument with the assistance of KEEN support. This group has used this survey with their students, which also allows the comparison of Baylor data to Rose Hulman data, and previous George Mason University data. The Rose Hulman team arranged for Baylor EGR 1301 students to take this survey online, after which the author downloaded the results via an internet link. A view of the web-interface portal is shown in Appendix A.

Fulcher's Curiosity Index self-assessment evolved from Ainley's ${ }^{7}$ breadth-and-depth conceptualization of curiosity. Breadth represents an orientation towards seeking varied and changing experiences. Depth indicates an orientation toward exploring and investigating new ideas. Thus, results from the survey include a breadth component, a depth component, and a "total" curiosity score. The survey itself consists of the 16 statements listed in Table IIA. Students self-report their level of agreement with each statement based on a six-point scale shown in Table IIB, ranging from $A=$ Disagree Strongly to $F=$ Agree Strongly.

\section{Table IIA: Curiosity Index Survey Statements}

\begin{tabular}{|ll|}
\hline 1. I spend a great deal of time researching areas that I wish to learn about in depth. \\
\hline 2. & When learning about something new, I try to find out everything I can about it. \\
\hline 3. I like variety in my life. \\
\hline 4. I rarely spend time investigating one thing. \\
\hline 5. I am always finding new things to do. \\
\hline $6 . \quad$ The more I learn about something, the more I want to learn about it. \\
\hline 7. I rarely try new things. \\
\hline 8. I seldom research a topic in great depth. \\
\hline 9. I am always trying out new things. \\
\hline 10. I often spend sustained periods of time investigating a topic of interest to me. \\
\hline 11. I prefer to mix up my days with a variety of activities. \\
\hline 12. I immerse myself in information pertaining to a topic that I find fascinating. \\
\hline 13. Very few things interest me. \\
\hline 14. I like to get involved in a wide-variety of activities. \\
\hline 15. When learning something, I try to gain the fullest possible understanding of the phenomenon. \\
\hline 16. I find myself fascinated by lots of different things \\
\hline
\end{tabular}

Proceedings of the 2017 ASEE Gulf-Southwest Section Annual Conference Organized by The University of Texas at Dallas Copyright (C) 2017, American Society for Engineering Education 


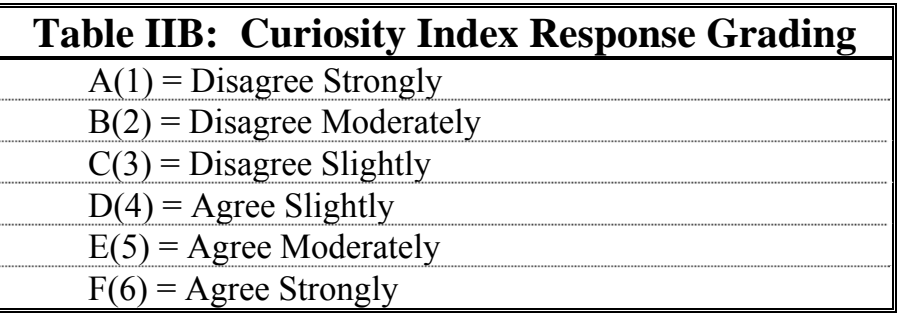

The Entrepreneurial Mindset self-assessment survey developed by Carpenter ${ }^{8}$ was administered near the end of the course. The survey consists of 29 statements shown in Table III to which students respond. These statements are grouped into the four broad categories of:

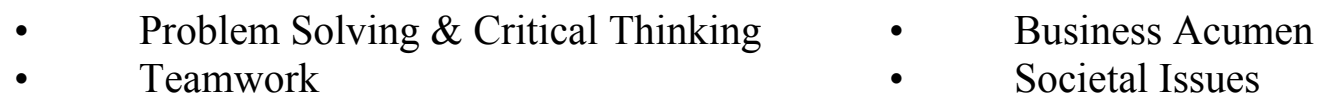

Students received a paper copy of the EM survey (shown in Appendix B) and manually marked their responses, which were subsequently entered into and analyzed in an Excel ${ }^{\circledR}$ spreadsheet.

\begin{tabular}{|l||}
\hline \multicolumn{1}{|c|}{ Table II: Entrepreneurial Mindset Survey Statements } \\
\hline - Problem Solving \& Critical Thinking \\
\hline 1. I am able to recognize problems that exist in the world around me. \\
\hline 2. I am good at devising multiple solutions when solving problems. \\
\hline 3. I continue trying even after I have failed. \\
\hline 4. I ask relevant questions to clarify situations and gain new knowledge. \\
\hline 5. I am always finding new things to do. \\
\hline 6. I am able to independently gain new information from various sources. \\
\hline 7. I accept responsibility for my personal actions. \\
\hline 8. I accept responsibility for the work I produce, including mistakes. \\
\hline 9. I think outside the box and am creative. \\
\hline - Teamwork \\
\hline 10. I understand and identify with the feelings, experiences, and motives of others. \\
\hline 11. I am aware of my personal strengths and weaknesses. \\
\hline 12. I can identify strengths and weaknesses in others. \\
\hline 13. I am able to determine whether I should lead or follow in different situations. \\
\hline 14. I can develop and maintain working relationships with peers. \\
\hline 15. I can develop and maintain working relationships with supervisors or superiors. \\
\hline 16. I am capable of resolving conflict. \\
\hline - Business Acumen \\
\hline 17. I am able to verbally organize and communicate ideas appropriate to the situation. \\
\hline 18. I am able to organize and communicate ideas in writing appropriate to the situation. \\
\hline 19. I understand basic principles of business. \\
\hline 20. I understand how marketing is used effectively within an organization. \\
\hline 21. I understand the concepts of finance in a business setting. \\
\hline 22. I assess opportunity and recognize unmet needs. \\
\hline 23. I assess and undertake reasonable risks. \\
\hline 24. I can develop my own vision. \\
\hline - Societal Issues \\
\hline 25. I think and behave ethically. \\
\hline 26. I am aware of how global issues influence society. \\
\hline 27. I serve the needs of others. \\
\hline 28. I try to make environmentally sensitive decisions. \\
\hline 29. I aim to make a positive impact on society. \\
\hline \hline
\end{tabular}

Proceedings of the 2017 ASEE Gulf-Southwest Section Annual Conference

Organized by The University of Texas at Dallas

Copyright @ 2017, American Society for Engineering Education 


\section{Results}

Among the three value-creation topics presented in EGR 1301 sections A and C, from an instructor's perspective, none of the three were greeted with high enthusiasm by the students as a whole. While the EM conversation within the engineering economics portion of the course provided a challenging perspective, students as a whole appeared more occupied with mastering how to solve moving-money-across-time problems using the interest-factor equations. The model bridge design project was enthusiastically embraced by the student teams, though the opportunity to improve bridge performance using wire cabling seemed of lower priority than using the ModelSmart ${ }^{\circledR}$ software to optimize the performance of the truss portion of their bridge. Only four of the eighteen teams incorporated the cabling in a meaningful fashion. The energy presentations near the end of the course allowed student teams to propose investigating a specific energy technology, and to expose its potential to create value. The value creation portion was not a major topic within any of the team presentations and in some presentations it seemingly received no consideration.

Results from the Curiosity Index self-assessment are intended to reveal the initial attitudes of the students as they enter the EGR 1301 course. Ninety-three different EGR 1301 students from four different EGR 1301 sections participated in the Curiosity Index self assessment. Average Total, Breadth, and Depth scores for the students from each of the four EGR 1301 sections are shown in Table IV. The scores from the EGR 1301 sections later exposed to EM topics overlap those from the EGR 1301 sections with no specific EM content. This overlap indicates there was little difference in the average curiosity disposition of the students among the four EGR 1301 sections.

\begin{tabular}{|c|c|c|c|c|}
\hline \multicolumn{5}{|c|}{ Table IV: Curiosity Index Results by EGR 1301 Section } \\
\hline Sections later exposed to EM topic & $\begin{array}{c}(\mathrm{Max}=96) \\
\text { Total }\end{array}$ & $\begin{array}{c}(\operatorname{Max}=36) \\
\text { Breadth }\end{array}$ & $\begin{array}{c}(\operatorname{Max}=36) \\
\text { Depth }\end{array}$ & $\begin{array}{c}\text { (out of 4) } \\
\text { Rank }\end{array}$ \\
\hline A (1) $n=36$ & 70.4 & 26.6 & 26.4 & 4 \\
\hline $\mathrm{C}(4) n=28$ & 74.3 & 28.4 & 27.6 & 1 \\
\hline \multicolumn{5}{|l|}{ Sections not exposed to EM topic } \\
\hline B (3) $n=28$ & 70.7 & 27.1 & 26.8 & 2 \\
\hline $\mathrm{D}(5) n=19$ & 71.8 & 27.5 & 27.2 & 3 \\
\hline
\end{tabular}

Students from five different EGR 1301 sections participated in the Entrepreneurial Mindset selfassessment survey. As this survey was administered near the end of the course, a comparison of average student attitudes was intended to determine if exposure to the EM topic value creation on three occasions affected their EM disposition. The results of the survey are shown below in Table V.

\begin{tabular}{|c|c|c|c|c|c|c|}
\hline \multicolumn{7}{|c|}{ Table V: Entrepreneurial Mindset Results by EGR 1301 Section } \\
\hline Sections exposed to EM topic & Total & $\begin{array}{l}\text { Prob Solv } \\
\text { Crit Think }\end{array}$ & $\begin{array}{l}\text { Team } \\
\text { Work }\end{array}$ & $\begin{array}{l}\text { Business } \\
\text { Acumen }\end{array}$ & $\begin{array}{c}\text { Societal } \\
\text { Issues }\end{array}$ & $\begin{array}{c}\text { (out of 4) } \\
\text { Rank }\end{array}$ \\
\hline A (1) $n=25$ & 4.18 & 4.31 & 4.16 & 3.95 & 4.40 & 3 \\
\hline $\mathrm{C}(4) n=30$ & 4.25 & 4.37 & 4.31 & 4.01 & 4.36 & 2 \\
\hline \multicolumn{7}{|l|}{ Sections not exposed to EM topic } \\
\hline B (3) $n=29$ & 4.31 & 4.41 & 4.45 & 4.09 & 4.29 & 1 \\
\hline $\mathrm{D}(5) n=20$ & 4.09 & 4.15 & 4.17 & 3.82 & 4.32 & 4 \\
\hline $\mathrm{E}(6) n=24$ & 4.27 & 4.36 & 4.30 & 4.03 & 4.51 & \\
\hline
\end{tabular}

Proceedings of the 2017 ASEE Gulf-Southwest Section Annual Conference Organized by The University of Texas at Dallas Copyright (C) 2017, American Society for Engineering Education 
Similar to the results from the Curiosity Index survey, those from the Entrepreneurial Mindset survey show that there is much overlap of the data between the participating EGR 1301 sections. Interestingly, when each of the four sections participating in both the Curiosity Index and Entrepreneurial Mindset self assessments are ranked, those EGR 1301 sections exposed to EM topics were ranked as highest and lowest average scores, and then at the end of the course were ranked are the middle two scores. Though as the average student scores on both self-assessment instruments considerably overlap, no conclusion can be drawn from this switching of ranks.

\section{Conclusions}

This study sought to expose students to the EM topic of value creation within a subset of freshman engineering course sections and without greatly affecting the overall structure of the course. The value creation coverage included a basic introduction within an engineering economics element, using supplemental cabling within a model bridge design project, and in association with investigating a novel/emerging energy-production technology. Fulcher's Curiosity Index self-assessment survey was used to measure entering student disposition and Carpenter's Entrepreneurship Mindset self-assessment was used to measure EM tendencies at the end of the course. These surveys were administered to students in the two sections with specific value creation content and also to sections where this topic was not highlighted.

Within the course, it did not appear that students embraced the value creation content. Concentrating on problem-solving equations, truss/bridge modeling software, and broader energy-technology topics received higher priority.

The results and comparison of the two self-assessment instruments show no differences between the student populations. The average response from students receiving specific value creation content was no different than that from the student in the other class sections.

Among the conclusions drawn from these results include that to effect student EM awareness, either more and/or different EM content needs to be included. From the instructor's perspective, students did not embrace the EM content. From a survey-data perspective, student attitudes toward EM at the end of the course was unaffected by the inclusion of the EM content.

During the following academic year a pilot version of EGR 1301 was offered that includes a number of contrasts compared to the current EGR 1301 standard. The co-instructors of this course include a previous KEEN Innovator and faculty member who participated in a KEEN ICE Workshop. Their work will include a greater number of EM topics and more engaging student opportunities than the efforts undertaken in this study and described in this report, and which the results of this study support. 
Appendix A: Curiosity Index Survey Internet Portal Interface 5,6

Curiosity Index (CI-4) Copyright @ 2004 James Madison University - Keston Fulcher I. BACKGROUND INFORMATION

B1. Which of the following best represents your disicipline/education at Baylor? Please select one

If "Other", please specify:

B2. What is your gender?

Female Male

B3. Which class section are you in?

Please select one

II. CURIOSITY INDEX (CI-4)

Please indicate your level of agreement with each of the statements below using the provided scale:

A=Disagree Strongly B=Disagree Moderately C=Disagree Slightly $\mathrm{D}=$ Agree Slightly E=Agree Moderately F=Agree Strongly

1. I spend a great deal of time researching areas that I wish to learn about in depth.

2. When learning about something new, I try to find out everything I can about it.

3. I like variety in my life.

4. I rarely spend time investigating one thing.

5. I am always finding new things to do.

6. The more I learn about something, the more I want to learn about it.

7. I rarely try new things.

8. I seldom research a topic in great depth.

9. I am always trying out new things.

10. I often spend sustained periods of time investigating a topic of interest to me.

11. I prefer to mix up my days with a variety of activities.

12. I immerse myself in information pertaining to a topic that I find fascinating.

13. Very few things interest me.

14. I like to get involved in a wide-variety of activities.

15. When learning something, I try to gain the fullest possible understanding of the phenomenon.

16. I find myself fascinated by lots of different things.

\section{Submit}

Styled by Timothy Chow, Director of Institutional Research (Rose-Hulman) 


\section{Appendix B ${ }^{6}$}

\section{Entrepreneurial Mindset Self-Assessment}

One of the initiatives of Baylor ECS is to increase entrepreneurial learning mindset of students. To help us along this path we ask that you complete this survey. This student self-assessment is brief and useful part of understanding how EGR 1301 students view their entrepreneurial attributes. The entrepreneurial mindset results in thinking in creative and innovative ways to solve problems and address societal needs. Some of the statements on the back of this sheet may not first appear to have a direct connection to entrepreneurship per se, yet they are related to the entrepreneurial mindset.

Please respond to the statements below and on the reverse side as honestly and fairly as you can in terms of how you think and/or behave in most situations. "Situations" may include classroom, groups, student activities, home, social situations or work. Please answer based on the situation or context that makes the most sense to you. There are no right or wrong responses, only honest ones. This survey is voluntary and you may skip any question you choose. Please select your level of agreement from Strongly Agree to Strongly Disagree for each of the statements.

Baylor University is a member of the Kern Entrepreneurship Education Network (KEEN) whose mission is to graduate engineers with an entrepreneurial mindset so they can create personal, economic, and societal value through a lifetime of meaningful work. On this project we're particularly indebted to fellow KEEN institutions Rose-Hulman Institute of Technology and Lawrence Technological University.

\begin{tabular}{|c|c|c|c|c|c|c|}
\hline$\underset{\#}{\text { Map }}$ & Entrepreneurial Mindset & $\begin{array}{c}5 \\
\text { Strongly } \\
\text { Agree }\end{array}$ & $\begin{array}{c}4 \\
\text { Agree }\end{array}$ & $\begin{array}{c}3 \\
\text { Neutral }\end{array}$ & $\begin{array}{c}2 \\
\text { Disagree }\end{array}$ & $\begin{array}{c}c 1 \\
\text { Strongly } \\
\text { Disagree }\end{array}$ \\
\hline \multicolumn{7}{|c|}{ PROBLEM SOLVING \& CRITICAL THINKING } \\
\hline 2 & $\begin{array}{l}\text { I am able to recognize problems that exist in } \\
\text { the world around me. }\end{array}$ & $\mathrm{O}$ & $\mathrm{O}$ & $\mathrm{O}$ & $\mathrm{O}$ & $\mathrm{O}$ \\
\hline 5 & $\begin{array}{l}\text { I am good at devising multiple solutions } \\
\text { when solving problems. }\end{array}$ & $\mathrm{O}$ & $\mathrm{O}$ & $\mathrm{O}$ & $\mathrm{O}$ & $\mathrm{O}$ \\
\hline 4 & I continue trying even after I have failed. & $\mathrm{O}$ & $\mathrm{O}$ & $\mathrm{O}$ & $\mathrm{O}$ & $\mathrm{O}$ \\
\hline 1 & $\begin{array}{l}\text { I ask relevant questions to clarify situations } \\
\text { and gain new knowledge. }\end{array}$ & $\mathrm{O}$ & $\mathrm{O}$ & $\mathrm{O}$ & $\mathrm{O}$ & $\mathrm{O}$ \\
\hline 1 & $\begin{array}{l}\text { I am able to independently gain new } \\
\text { information from various sources. }\end{array}$ & $\mathrm{O}$ & $\mathrm{O}$ & $\mathrm{O}$ & $\mathrm{O}$ & $\mathrm{O}$ \\
\hline 4 & $\begin{array}{l}\text { I accept responsibility for my personal } \\
\text { actions. }\end{array}$ & $\mathrm{O}$ & $\mathrm{O}$ & $\mathrm{O}$ & $\mathrm{O}$ & $\mathrm{O}$ \\
\hline 4 & $\begin{array}{l}\text { I accept responsibility for the work I } \\
\text { produce, including mistakes. }\end{array}$ & $\mathrm{O}$ & $\mathrm{O}$ & $\mathrm{O}$ & $\mathrm{O}$ & $\mathrm{O}$ \\
\hline 1 & I think outside the box and am creative. & $\mathrm{O}$ & $\mathrm{O}$ & $\mathrm{O}$ & $\mathrm{O}$ & $\mathrm{O}$ \\
\hline
\end{tabular}




\begin{tabular}{|c|c|c|c|c|c|c|}
\hline$\underset{\#}{\text { Map }}$ & Entrepreneurial Mindset & $\begin{array}{c}5 \\
\text { Strongly } \\
\text { Agree }\end{array}$ & $\begin{array}{c}4 \\
\text { Agree }\end{array}$ & $\begin{array}{c}3 \\
\text { Neutral }\end{array}$ & $\begin{array}{c}2 \\
\text { Disagree }\end{array}$ & $\begin{array}{c}1 \\
\text { Strongly } \\
\text { Disagree }\end{array}$ \\
\hline \multicolumn{7}{|c|}{ TEAMWORK } \\
\hline 1 & $\begin{array}{l}\text { I understand and identify with the feelings, } \\
\text { experiences, and motives of others. }\end{array}$ & $\mathrm{O}$ & $\mathrm{O}$ & $\mathrm{O}$ & $\mathrm{O}$ & $\mathrm{O}$ \\
\hline 3 & $\begin{array}{l}\text { I am aware of my personal strengths and } \\
\text { weaknesses. }\end{array}$ & $\mathrm{O}$ & $\mathrm{O}$ & $\mathrm{O}$ & $\mathrm{O}$ & $\mathrm{O}$ \\
\hline 3 & $\begin{array}{l}\text { I can identify strengths and weaknesses in } \\
\text { others. }\end{array}$ & $\mathrm{O}$ & $\mathrm{O}$ & $\mathrm{O}$ & $\mathrm{O}$ & $\mathrm{O}$ \\
\hline 3 & $\begin{array}{l}\text { I am able to determine whether I should } \\
\text { lead or follow in different situations. }\end{array}$ & $\mathrm{O}$ & $\mathrm{O}$ & $\mathrm{O}$ & $\mathrm{O}$ & $\mathrm{O}$ \\
\hline 4 & $\begin{array}{l}\text { I can develop and maintain working } \\
\text { relationships with peers. }\end{array}$ & $\mathrm{O}$ & $\mathrm{O}$ & $\mathrm{O}$ & $\mathrm{O}$ & $\mathrm{O}$ \\
\hline 4 & $\begin{array}{l}\text { I can develop and maintain working } \\
\text { relationships with supervisors or superiors. }\end{array}$ & $\mathrm{O}$ & $\mathrm{O}$ & $\mathrm{O}$ & $\mathrm{O}$ & $\mathrm{O}$ \\
\hline 4 & I am capable of resolving conflict. & $\mathrm{O}$ & $\mathrm{O}$ & $\mathrm{O}$ & $\mathrm{O}$ & $\mathrm{O}$ \\
\hline \multicolumn{7}{|c|}{ BUSINESS ACUMEN } \\
\hline 2 & $\begin{array}{l}\text { I am able to verbally organize and com- } \\
\text { municate ideas appropriate to the situation. }\end{array}$ & $\mathrm{O}$ & $\mathrm{O}$ & $\mathrm{O}$ & $\mathrm{O}$ & $\mathrm{O}$ \\
\hline 2 & $\begin{array}{l}\text { I am able to organize and communicate } \\
\text { ideas in writing appropriate to the situation. }\end{array}$ & $\mathrm{O}$ & $\mathrm{O}$ & $\mathrm{O}$ & $\mathrm{O}$ & $\mathrm{O}$ \\
\hline 7 & I understand basic principles of business. & $\mathrm{O}$ & $\mathrm{O}$ & $\mathrm{O}$ & $\mathrm{O}$ & $\mathrm{O}$ \\
\hline 7 & $\begin{array}{l}\text { I understand how marketing is used } \\
\text { effectively within an organization. }\end{array}$ & $\mathrm{O}$ & $\mathrm{O}$ & $\mathrm{O}$ & $\mathrm{O}$ & $\mathrm{O}$ \\
\hline 7 & $\begin{array}{l}\text { I understand the concepts of finance in a } \\
\text { business setting. }\end{array}$ & $\mathrm{O}$ & $\mathrm{O}$ & $\mathrm{O}$ & $\mathrm{O}$ & $\mathrm{O}$ \\
\hline 6 & $\begin{array}{l}\text { I assess opportunity and recognize unmet } \\
\text { needs. }\end{array}$ & $\mathrm{O}$ & $\mathrm{O}$ & $\mathrm{O}$ & $\mathrm{O}$ & $\mathrm{O}$ \\
\hline 3 & I assess and undertake reasonable risks. & $\mathrm{O}$ & $\mathrm{O}$ & $\mathrm{O}$ & $\mathrm{O}$ & $\mathrm{O}$ \\
\hline 2 & I can develop my own vision. & $\mathrm{O}$ & $\mathrm{O}$ & $\mathrm{O}$ & $\mathrm{O}$ & $\mathrm{O}$ \\
\hline \multicolumn{7}{|c|}{ SOCIETAL ISSUES } \\
\hline 5 & I think and behave ethically. & $\mathrm{O}$ & $\mathrm{O}$ & $\mathrm{O}$ & $\mathrm{O}$ & $\mathrm{O}$ \\
\hline 1 & $\begin{array}{l}\text { I am aware of how global issues influence } \\
\text { society. }\end{array}$ & $\mathrm{O}$ & $\mathrm{O}$ & $\mathrm{O}$ & $\mathrm{O}$ & $\mathrm{O}$ \\
\hline 6 & I serve the needs of others. & $\mathrm{O}$ & $\mathrm{O}$ & $\mathrm{O}$ & $\mathrm{O}$ & $\mathrm{O}$ \\
\hline 6 & $\begin{array}{l}\text { I try to make environmentally sensitive } \\
\text { decisions. }\end{array}$ & $\mathrm{O}$ & $\mathrm{O}$ & $\mathrm{O}$ & $\mathrm{O}$ & $\mathrm{O}$ \\
\hline 6 & I aim to make a positive impact on society. & $\mathrm{O}$ & $\mathrm{O}$ & $\mathrm{O}$ & $\mathrm{O}$ & $\mathrm{O}$ \\
\hline
\end{tabular}

Proceedings of the 2017 ASEE Gulf-Southwest Section Annual Conference 


\section{References}

Yoder, J.D., Kleine, R., Carpenter, D., Fry, C., Spreading the Fire: Broadening Faculty Support for the Entrepreneurial Mindset, Proceedings of the NCIAA $17^{\text {th }}$ Annual Conference, March 22-23, 2013, 11 pps. ${ }^{2}$ Jordan, W.M., Fry, C.C., Van Treuren, K.W., Promoting the Entrepreneurial Mindset through Faculty Development, Proceedings of the $123^{\text {rd }}$ ASEE Annual Conference, New Orleans, LA, June 26-29, 2016, 14 pps.

${ }^{3}$ Van Treuren, K., Jordan, W., Fry, C, Instilling the Entrepreneurial Mindset in Engineering Undergraduates at Baylor University, Proceedings of the ASEE Gulf-Southwest Annual Regional Conference, Fort Worth, TX, March 8-16, 2016.

${ }^{4}$ Gerhart, A.L., Carpenter, D.D., Fletcher, R.W., Meyer, E.G., Combining Discipline-specific Introduction to Engineering Courses into a Single Multi-discipline Course to Foster the Entrepreneurial Mindset with Entrepreneurially Minded Learning, Proceedings of the $121^{\text {st }}$ ASEE Annual Conference, Indianapolis, IN, June 1518, 2014, pg 24.2881-24.288.30.

${ }^{5}$ Fulcher, K.H., Curiosity: A Link to Assessing Lifelong Learning, Assessment Update, March-April 2008, Vol 20 №2, pp. 5-7.

${ }^{6}$ Williams, J.W., Curiosity Index: Assessing a Disposition for Entrepreneurship, A KEEN Webinar, January 6, 2014, http://engineeringunleashed.com/keen/keen-webinar-the-curiosity-index/

${ }^{7}$ Ainley, M.D. The Factor Structure of Curiosity Measures: Breadth and Depth of Interest Curiosity Styles, Australian Journal of Psychology, 1987, Vol. 39, №1, pp 53-59.

${ }^{8}$ Gerhart, A., Carpenter, D., Grunow, M., Hayes, K., Development of a Leadership and Entrepreneurship SkillsAssessment Instrument, Proceedings of the 2010 ASEE Annual Conference, Louisville, KY, June 20-23, 2010, pg. 15.403.1-15.403.21.

\section{Benjamin S. Kelley}

Dr. Benjamin S. Kelley is Professor of Mechanical Engineering in the School of Engineering and Computer Science at Baylor University. He also directs the General Engineering BSE degree program. Previously at Baylor he served as dean of the school. Before coming to Baylor he was a faculty member and administrator in the School of Engineering at Mercer University. Dr. Kelley has also completed visiting faculty appointments at Duke University, the University of Pittsburgh, and in Kazakhstan and Vietnam, where he was appointed the first VEF U.S. Faculty Scholar. His area of technical expertise is orthopedic biomechanics and cardiovascular dynamics. He has received several engineering teaching and advising awards. 